\title{
Monitoring training loads in elite tennis
}

\author{
Monitoramento das cargas de treinamento no tênis de elite
}

Aaron James Coutts Rodrigo Vitasovic Gomes 2 Luis Viveiros Marcelo Saldanha Aoki ${ }^{4}$

1 University of Technology of Sydney. School of Leisure, Sport \& Tourism, Lindfield, NSW, Australia;

2 University of São Paulo. School of Physical Education and Sport, São Paulo, SP, Brazil;

3 Department of Technology and Science, Brazilian Olympic Committee, Rio de Janeiro, RJ, Brazil;

4 University of São Paulo. School of Arts, Sciences and Humanities, São Paulo, SP, Brazil.

Recebido em 07/02/09 Revisado em 01/04/09 Aprovado em 27/11/09
Abstract - Training load (TL) is influenced by both training volume and training intensity. A precise understanding of the TLs completed during training is crucial to achieve desirable training outcomes and to avoid overtraining. TL can be monitored in many different ways; however, we recommend the session-rate of perceived exertion (session-RPE) method for quantifying TL because of its low cost and because it is easy to understand and relatively simple to implement. In this report, we provide data regarding TLs collected during the 2008 Roland Garros Tournament. Our experience in tennis suggests the session-RPE method to be a valuable tool that can be used to control training and to avoid excessive TLs. We also believe that accurate monitoring of TL will enable the coach to better understand of the sports training process, ultimately leading to the improvement of performance.

Key words: Session-RPE; Periodization; Internal training load; External training load.

Resumo - A carga de treinamento (CT) é influenciada pelo volume e pela intensidade. A determinação precisa das CTs utilizadas durante o treinamento é crucial para atingir as adaptações desejadas e evitar o overtraining. A CT pode ser monitorada de diversas maneiras. Entretanto, nós recomendamos o método da percepção subjetiva de esforço da sessão (PSE da sessão) para quantificar a CT pelo seu baixo custo, pela sua fácil compreensão e a pela sua relativa simplicidade de implementação. Neste relato, nós apresentamos dados relacionados às CTs coletados durante o Torneio de Roland Garros em 2008. Nossa experiência no tênis sugere que o método da PSE da sessão é uma ferramenta valiosa que pode ser usada para controlar o treinamento e evitar CTs excessivas. Nós também acreditamos que o monitoramento preciso da CT proporcionará ao técnico o melhor entendimento do processo de treinamento desportivo, em última instância, levando ao aumento de desempenho.

Palavras-chave: PSE da sessão; Periodização; Carga interna de treinamento; Carga externa de treinamento. 


\section{INTRODUCTION}

To assess the effectiveness of the training process, sports coaches require the ability to monitor training load (TL). Accurate monitoring of TL will enable the coach to assess whether the training stimulus has been applied as intended and will provide information for planning future training. In this report, we focus on the importance of TL monitoring and explain a simple method that might be used to monitor TLs. First, we provide a general overview and definitions of important training variables (i.e., training volume, training intensity and TL), and then we demonstrate how a simple method of TL monitoring was applied to a top-level tennis player.

Training volume usually refers to the duration of training. In general, coaches report training volume in terms of time (i.e., min.day ${ }^{1}$, hours. week $\left.^{1}\right)$. However, it can also be reported in terms of distance covered (i.e., 80 km.week $^{1}$ for a runner or $300 \mathrm{~km}$. week $^{1}$ for a cyclist). Training intensity refers to how hard an athlete is training. Many methods can be used to measure intensity, including heart rate, oxygen consumption, weight lifted, power output, blood lactate concentration, or the rate of perceived exertion $(\mathrm{RPE})^{1-5}$. Most sports coaches manipulate both training intensity and volume in their training programs. Therefore, independent measurement of volume and intensity may not truly reflect the training stress imposed on the athlete. In this respect, the calculation of TL has been suggested for the evaluation of training stress ${ }^{2}$. TL is simply the function of training volume and training intensity and can be calculated using the following equation: $\mathrm{TL}=$ training volume $\mathrm{x}$ training intensity. Many different methods of recording TLs in sports have been reported ${ }^{5}$, including the measurement of heart rate, distance covered during training or total weight lifted during training. However, for the coach, these methods can be complicated or may not be useful since they do not take into account training volume and intensity at the same time. Fortunately, a relatively simple method for quantifying TLs in a variety of different training modalities into one simple arbitrary number has been developed ${ }^{2}$. This method is commonly known as the session-RPE method. This method of TL monitoring in team sports requires the athlete to provide an RPE for each exercise session together with a measure of training duration ${ }^{2}$. To assess the intensity of the training session, athletes are asked within 30-minutes after the end of their workout a simple question such as "How was your workout?". The coach must be sure that the athletes understand that this number is an overall value of intensity that corresponds to the whole training session. A single number representing the magnitude of TL for each session is then calculated by the multiplication of training intensity ( $\mathrm{TL}=$ session-RPE $\mathrm{x}$ duration in minutes). The TL for a 40-minute training session, with an RPE of the athlete of 5.5 (HARD), would be calculated as follows: $\mathrm{TL}=5.5 \times 40=220$ arbitrary units (AU). The modified CR-10 RPE scale is used for athletes to classify their perceived intensity of each training session ${ }^{2}$. The major advantage of the session-RPE method over other reported methods for the quantification of TLs is that it is a simple measure and relatively easy to interpret. Recent studies have shown that the session-RPE method compares favorably with the more complicated methods of quantifying TLs in endurance sports ${ }^{2,6}$, team sports ${ }^{3,4}$, and resistance training ${ }^{7,8}$. These recent findings demonstrate that the session-RPE method is a valid and reliable tool for training monitoring. The aim of the present study was to describe the session-RPE method for TL assessment and to provide data regarding TL measures obtained during the 2008 Roland Garros Tournament.

\section{METHODS}

\section{Case study}

A top-level tennis player (ATP ranking: $78^{\text {th }}, 1.87$ m, $82 \mathrm{~kg}, 20$ years, HRmax $=187 \mathrm{bpm}$ ) agreed to participate in this study during his preparation for the 2008 Roland Garros Tournament and during the competition. The study was approved by the Institutional Ethics Review Board (CEP EEFEUSP\#15).

\section{Training load assessment}

The session-RPE was determined as described by Foster et al.'. 'The athlete's' session-RPE was collected 30 minutes after each training session to ensure that the perceived effort corresponded to the whole session rather than the most recent exercise intensity. The coach's session-RPE was collected before each training session. The magnitude of TL (AU) for each session was calculated by the multiplication of training intensity $(\mathrm{TL}=$ session-RPE $\mathrm{x}$ duration in minutes).

The method proposed by Edwards ${ }^{8}$ determines internal TL by multiplying the accumulated training duration (minutes) of five HR zones by a relative coefficient for each zone (50-60\% of HR- 
$\max =1,>60-70 \%$ of HRmax $=2,>70-80 \%$ of HRmax $=3,>80-90 \%$ of HRmax $=4,>90-100 \%$ of HRmax $=5$ ) and then summing the results.

\section{RESULTS}

Figure 1A shows an example of a weekly TL during preparation for the 2008 Roland Garros Tournament. The total TL assessed by the session-RPE method was 2380 AU. Figure 1B shows the comparison between the designed TLs (coach) and the experienced TLs (athlete). This comparison provides valuable feedback information for the coach to monitor athlete internal loads compared to external intended loads.
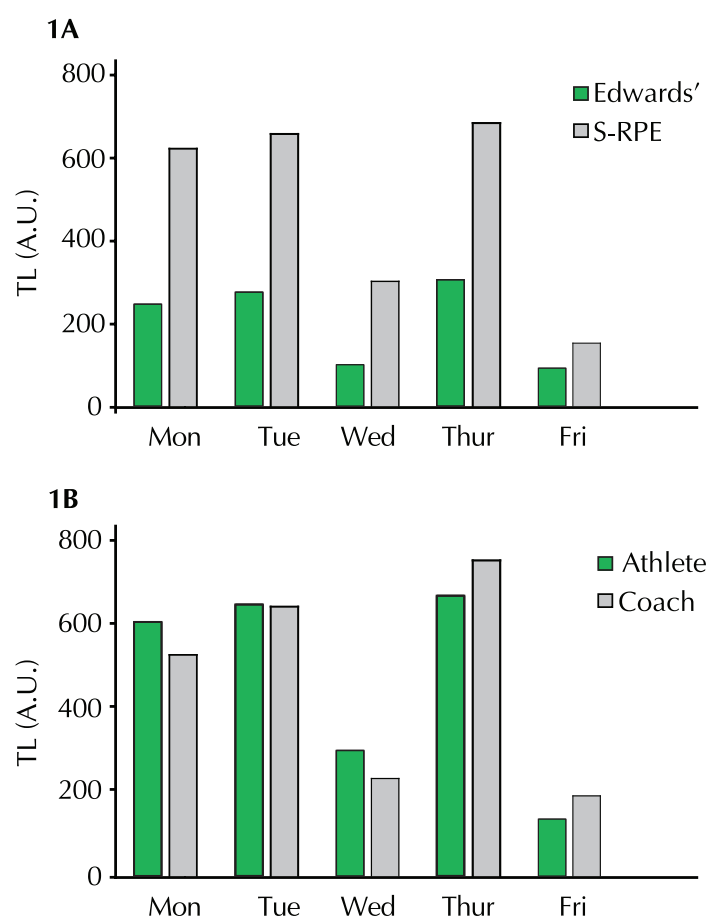

Figure 1. Weekly training load ( $T L$, in $\mathrm{AU}$ ) assessed by the session-RPE method and by Edwards' methods (A) and weekly TL (AU) assessed by the session-RPE method as designed by the coach and as experienced by the athlete (B) during preparation for the 2008 Roland Garros Tournament.

Table 1 shows the TL assessment during each match of the 2008 Roland Garros Tournament. Total TL completed during the tournament was 18\% (2908 AU) higher than during the previous week of training.

Table 1. Training load (TL) variables during the 2008 Roland Garros Tournament.

\begin{tabular}{lcccc}
\hline & $1^{\text {st }}$ match & $2^{\text {nd }}$ match & $3^{\text {rd }}$ match & $4^{\text {th }}$ match \\
\hline Duration (min) & 80 & 140 & 74 & 154 \\
Session-RPE & 6 & 7 & 5 & 7 \\
TL (AU) & 480 & 980 & 370 & 1078 \\
\hline
\end{tabular}

\section{DISCUSSION}

In this case study, we report data regarding TL monitoring in a top-level tennis player using sessionRPE and HR-based methods. TLs were assessed during physical training preparation for the 2008 Roland Garros Tournament. The TL of each match was also assessed during the tournament using the session-RPE method.

The TL data shown here were collected in the last week before the tournament (weekly TL $=2380$ AU). TLs calculated by the session-RPE method have been shown to be similar to those assessed by the method of Edwards ${ }^{4,8}$. During this period, the sports conditioning coach tends to increase intensity and to reduce volume. As expected, a mild decrease in weekly TLs was observed when compared to the previous cycle. This trend of reduced TLs before a competition is also apparent in other team sports ${ }^{5,9,10}$. We also observed a similar decrease in TL during tapering for the 2008 Roland Garros Tournament. It is well known that optimal TL is crucial to achieve training outcomes and to improve performance. Furthermore, variation in TLs (i.e., periodization) has been shown to be more effective in improving performance than continuously high or low loads ${ }^{11}$. On the other hand, excessive/monotonous TL stimuli might reduce performance ${ }^{12}$. In a recent study, a weekly total TL of more than 6000 AU (i.e., 20 hours of HARD training) was found to result in symptoms of overreaching in eight well-trained male triathletes ${ }^{13}$. Interestingly, the TLs observed prior to and during the 2008 Roland Garros Tournament are similar to the TLs of professional football players during the competition season ${ }^{5}$. The session-RPE method is a useful tool for monitoring TLs during training and competition. However, more data are necessary to validate this method in tennis.

The total TL during the tournament was higher than the total TL during the last week of preparation ( 2380 vs. $2908 \mathrm{AU}$ ). This result is also expected since many other factors might influence overall perception of effort during a competition, therefore increasing the TL. During this particular period, the coach should accurately monitor TLs to avoid excessive stimuli and to maximize recovery. This information can be used as the logical basis for training periodization during a tournament.

\section{PRACTICAL APPLICATIONS}

The close monitoring of an athlete's TLs in combination with simple measures of fatigue and 
fitness can provide important information that form the basis for future training periodization. The coach will have a more precise understanding of the athlete's tolerance to training and will be able to titrate future loads that best suit individual athletes. The session-RPE method can be used to maximize training outcomes by ensuring a proper control of training and monitoring the athlete's internal loads compared to intended loads (as shown in Figure 1B). This method can also be used to identify athletes who are not coping with training, to compare athletes' individual loads to the mean TL of a team/squad, and to assess TLs during rehabilitation after injury ${ }^{5}$.

\section{CONCLUSION}

TLs can be monitored in many different ways; however, we recommend the session-RPE method for quantifying TLs because of its low cost and because it is easy to understand and relatively simple to implement. The method permits sufficient TLs to be implemented and excessive loads to be avoided. We believe that the session-RPE method can be used in tennis, but further studies are necessary to validate the method in this sport.

\section{Acknowledgments}

Rodrigo V. Gomes would like to thank CAPES for the scholarship. We also would like to thank the CNPq (Grant \# 563967/2008-0) for funding this research.

\section{REFERENCES}

1. Day M, McGuigan MR, Brice G, Foster C. Monitoring exercise intensity during resistance training using the session-RPE scale. J Strength Cond Res 2004;18(2):353-358.

2. Foster C, Florhaug JA, Franklin J, Gottschall L, Hrovatin LA, Parker S, Doleshal P, Dodge C. A new approach to monitoring exercise training. J Strength Cond Res 2001;15(1):109-115.

3. Alexiou H, Coutts AJ. The validity of the sessionRPE method for monitoring training load in elite female soccer players. Int J Sports Physiol Performance 2008;3(3):320-330.
4. Impellizzeri FM, Rampinini E, Coutts AJ, Sassi A, Marcora, SM. Use of RPE-based training load in soccer. Med Sci Sports Exerc 2004;36(6): 1042-1047.

5. Coutts AJ, Charmari K, Rampinini E, Impellizzeri FM. Contrôle et suivi de l'entraînement: périodisationet charges d'entraînement, in De L'entraînement à la Performance en Football A. Dellal, Editor. 2008. p.242-263.

6. Wallace LK, Slattery KM, Coutts AJ. The ecological validity and application of the session-RPE method for quantifying training loads in swimming. J Strength Cond Res 2009;23(1):33-38.

7. Sweet TW, Foster C, McGuigan MR, Brice G. Quantitation of resistance training using the session rating of perceived exertion method. J Strength Cond Res 2004;18(4):796-802.

8. Edwards S. High performance training and racing, in The Heart Rate Monitor Book. In. Edwards S. editor. 1993, Feet Fleet Press: Sacramento, CA. p.113-123.

9. Coutts A, Reaburn P, Piva TJ, Murphy A. Changes in selected biochemical, muscular strength, power, and endurance measures during deliberate overreaching and tapering in rugby league players. Int J Sports Med 2007;28(2):116-124.

10. Coutts AJ, Sirotic AC. Monitoring training loads in top-level professional rugby league. J Sports Sci Med 2007;6(10):75.

11. Foster, C. Monitoring training in athletes with reference to overtraining syndrome. Med Sci Sports Exerc 1998;30(7):1164-1168.

12. Bruin G, Kuipers H, Keizer HA, Vander Vusse GJ. Adaptation and overtraining in horses subjected to increasing training loads. J Appl Physiol 1994;76(5):1908-1913.

13. Coutts AJ, Slattery KM, Wallace LK. Practical tests for monitoring fatigue and recovery in triathletes. J Sci Med Sport 2007;10(6):372-381. 